AGRICULTURE AND BIOLOGY JOURNAL OF NORTH AMERICA

ISSN Print: 2151-7517, ISSN Online: 2151-7525, doi:10.5251/abjna.2010.1.5.845.858

(C) 2010, ScienceHuß, http://www.scihub.org/ABJNA

\title{
Evaluation of some extra-early- and early-maturing cowpea varieties for intercropping with maize in southern Guinea Savanna of Nigeria
}

\author{
Egbe, O.M, Alibo, S.E and Nwueze, I \\ Department of Crop Production,University of Agriculture,Makurdi.
}

\begin{abstract}
Two field experiments were undertaken between 2008 and 2009 at the Teaching and Research Farm of the University of Agriculture,Makurdi and at the National Root Crops Research Institute Sub-Station, Otobi (both located in Southern Guinea Savanna agro ecological zone of Nigeria) to evaluate fourteen improved extra-early- and early-maturing cowpea varieties in sole and in intercropping systems. The work aimed at assessing the productivity of these cowpea varieties and competitive interactions with the maize component as well as the profitability of cowpea/maize intercropping systems. The first experiment was laid out in randomized complete block design with three replications in each of the two locations. IT04K-221-1, IT03K-3161,IT03K-324-9,IT03K-351-1,IT00K-1217, IT98K-692, IT99K-377-1, IT03K-378-4 cowpea varieties proved superior to the Ife Brown(check) in number of pods produced per plant, dry pod weight and grain yield, and therefore were selected for further investigation under intercropping .Grain yield advantage of IT04K-221-1 over Ife Brown was370.69\%. The selected cowpea varieties, along with the Ife Brown(check), were intercropped with maize in split-plot experiment laid out in randomized complete block design with three replications at Otobi for two seasons.. Intercropping depressed the number of branches per plant and the dry grain yield of cowpea but did not influence the number of pods per plant, number of seeds per pod and the pod length of cowpea. Maize grain yield reductions resulting from intercropping varied from $49.26 \%$ to $72.41 \%$, depending on the cowpea variety. Intercrop advantages measured by land equivalent ratio, area $x$ time equivalency ratio; land equivalent coefficient indicated that IT04K-221-1, IT03K-316-1, IT03K-324-9, IT98K-692 and IT00K-2117 proved most productive under intercropping. Competitive indices (competitive ratio and aggressivity) showed that cowpea was the more competitive component of the intercropping. Sole cowpea had a mean net benefit of $-\mathrm{N560.00/ha,}$ while intercropped cowpea gave a mean value of $N 11330.00 / h a$, implying that growing extraearly- and early-maturing cowpea in sole systems would result in losses. Intercropped IT04K-2211 produced the largest net benefit ( $\mathbb{N} 42425.00 / h a)$, while IT03K-378-4 gave the lowest (- $\mathbb{N}$ $16300.00 / \mathrm{ha})$.
\end{abstract} \section{INTRODUCTION:}

Keywords: cowpea varieties, intercropping, competition, net benefit.

Cowpea (Vigna unguiculata (L.) Walp.) is a major food crop in sub-Saharan Africa, especially in the dry regions of West Africa (Singh and Ntare,1985), with the seeds as a major source of plant proteins and vitamins for man, feed for animals, and also a cashearner for the rural farmers. The young leaves and immature pods are eaten as vegetables. Nigeria is the world's largest producer of cowpea, and substantial amounts come from Niger,Burkina-Faso and Ghana(Craufurd,1996). In the West African region, where more than 70 per cent of the total world production is grown, cowpea has become an integral part of the farming system (Ogbuinya, 1997) and grown in mixtures with other crops in various combinations (Olufajo and Singh, 2002).In Benue
State, located in the Southern Guinea Savanna of Nigeria, 272,270 metric tonnes of cowpea was produced from over 300,000 hectares of land in 2009(BNARDA, 2009). In this region, the bulk of cowpea production is by small-scale farmers using the traditional system of mixed intercropping with maize, sorgum, millet, yam, cassava, pepper and other vegetable crops. The productivity of cowpea in these mixtures is often very low(0.3-1.0 $\mathrm{t} / \mathrm{ha}$ )(BNARDA,2009), due in part to unavailability of improved cowpea varieties, insect pests, diseases and even mammalian and avian pests .Farmers' preference for extra-early- and early-maturing cowpea lines in Southern Guinea Savanna is similar to other regions of Nigeria. This preference for extraearly-and early-maturing crop varieties, particularly 
cowpea has been well documented (Singh et al., 2007).

Although several studies on cowpea/maize intercropping undertaken elsewhere have been reported with varied intercrop advantages (Blade et al., 1992; Ezumah and Ikorgu, 1992; Singh and Ajeigbe, 2007; Katsaruware and Manyanhaire, 2009), emphasis on the use of short duration cowpea varieties has been negligible. In Southern Guinea Savanna region of Nigeria, there is dearth of documented information on cowpea/maize intercropping involving extra-early- and earlymaturing varieties of cowpea. Previous research work had shown that improving the productivity of cowpea/cereal intercropping lies in the performance of the cowpea component which include among other things the choice of appropriate genotype. Snapp and Silim (2002) had indicated that technologies that improve productivity and appear to be biologically sound had been rejected by farmers, and therefore advised that crop improvement strategies aimed at translating benefits to small-scale farmers must keep farmer preferences and belief systems in the forefront. The choice of cowpea varieties for this research work bore in mind the farmers' preference for extra-early- and early-maturing cowpea lines. The study aimed at (i ) evaluating fourteen improved extra-early- and early-maturing cowpea varieties for intercropping with maize with a view to assess their productivity and competitive interactions with the maize component in Southern Guinea Savanna of Nigeria. (ii) improving the productivity and assessing the profitability of cowpea/maize intercropping systems with consequent impacts on food security of the region.

\section{MATERIALS AND METHODS:}

Two field experiments were carried out during the wet seasons (June-November) of 2008 and (AprilNovember ) of 2009 at the Teaching and Research Farm of the University of Agriculture, Makurdi( Latitude $07^{0} 45^{\prime}-07^{0} 50^{\prime} \mathrm{N}$, Longitude $08^{0} 45^{\prime}-08^{\circ}$ $50^{\prime} \mathrm{E}$, elevation $98 \mathrm{~m}$ ) and the National Root Crops Research Institute Sub-Station, Otobi (Latitude $07^{\circ}$ $10^{\prime} \mathrm{N}$, Longitude $08^{\circ} 39^{\prime} \mathrm{E}$, elevation $105.1 \mathrm{~m}$ ) all located in Southern Guinea Savanna agro-ecological zone of Nigeria(Kowal and Knabe,1972).The experimental sites received a total rainfall of 1133.5 $\mathrm{mm}$ and $1453.3 \mathrm{~mm}$, respectively in 2008 and 1234.4 $\mathrm{mm}$ and $1543.6 \mathrm{~mm}$, respectively in 2009 . Fifteen core samples collected from $0-30 \mathrm{~cm}$ depth at each experimental site before land preparation were bulked, air-dried and ground. Samples were sieved through $2 \mathrm{~mm}$ and $0.05 \mathrm{~mm}$ screens for determination of particle size, $\mathrm{pH}$, total nitrogen $(\mathrm{N})$, organic carbon $(C)$, available phosphorus $(P)$ and potassium $(K)$. The texture of the top soil $(0-30 \mathrm{~cm})$ of both experimental sites was sandy loam. While soil at the experimental site at Makurdi was classified as Dystric Ustropept (USDA), the soil at Otobi was classified as Typic Paleustalf (USDA).The level of total nitrogen $(\mathrm{N})$ was $155 \mathrm{mg} \mathrm{kg}^{-1}$ soil, phosphorus and potassium averaged 520 and $135 \mathrm{mg} \mathrm{kg}^{-1}$ soil, respectively and organic carbon was $1540 \mathrm{mg} \mathrm{kg}-1$ in Makurdi. In Otobi, the level of total nitrogen $(\mathrm{N})$ was $910 \mathrm{mg} \mathrm{kg}^{-1}$, available $\mathrm{P}$ (Bray 1 ) and $\mathrm{K}$ averaged 370 and $15 \mathrm{mg} \mathrm{kg}^{-1}$ and organic carbon measured $2210 \mathrm{mg} \mathrm{kg}^{-1}$. The various procedures used for soil analysis were as outlined by Jackson (1967).

Experiment 1: Evaluation of 14 improved extraearly- and early-maturing cowpea varieties along with one local check in sole system. Improved cowpea varieties obtained from International Institute of Tropical Agriculture (IITA), Ibadan were grown in sole cropping at both experimental sites in randomized complete block design with three replications. The cowpea varieties used in the experiment were:
1. IT03K-378-4
2. IT03K-316-1
3. ITOOK-1207
4. IT98-133-1-1
5. IT99K-377-1
6. IT99K-216-44
7. IT03K-324-9
8. ITO3K-351-1
9. IT00K-1217
10. IT98K-692
11. IT04K-217-5
12. IT03K-369-3
13. IT04K-221-1
14. IT99K-530-1
15. Ife Brown (local check)

The local check was obtained from a local market in Otobi in Benue State.

The gross plot comprised of 4 rows spaced $50 \mathrm{~cm}$ apart and $4 \mathrm{~m}$ long $\left(8 \mathrm{~m}^{2}\right)$, while the net plot was made up of the two inner rows and $2 \mathrm{~m}$ long (2 $\mathrm{m}^{2}$ ).Land preparation was done manually using traditional implements. Fertilizer application was done at the rate of $200 \mathrm{~kg} \mathrm{NPK}: 15: 15: 15\{30 \mathrm{~kg} \mathrm{~N}, 30 \mathrm{~kg}$ $\mathrm{P}_{2} \mathrm{O}_{5}, 30 \mathrm{~kg} \mathrm{~K} \mathrm{O}_{2}$ per hectare (ha)\} before planting as recommended by BNARDA (2003) for cowpea production in Benue State of Nigeria. Planting was done by dibbling three seeds per hill at the depth of 3 
Agric. Biol. J. N. Am., 2010, 1(5): 845-858

$\mathrm{cm}$ and spaced $20 \mathrm{~cm}$, intra-row on the $30^{\text {th }}$ of August and $2^{\text {nd }}$ of September, 2008 at Otobi and Makurdi, respectively. The seedlings were thinned to two per stand at two weeks after planting( WAP).All other agronomic practices as recommended for cowpea production by BNARDA (2003) were strictly followed. Three insecticidal applications were done at fortnightly intervals, beginning at appearance of first flower. The insecticide used was Action ${ }^{\circledR}$ (Dimethoate $40 \mathrm{EC}$ at $0.04 \mathrm{~g}$ a.i.) applied at the rate of $50 \mathrm{ml}$ per 20 liters of water in a knapsack sprayer. Harvesting was done when $95 \%$ of the pods had dried. Two pickings were done for each treatment plot. Pods were dried for at least 8 hours per day in the sun for one week, then threshed and winnowed. Data collected included:days to $50 \%$ flowering, days to maturity, number of pods per plant at maturity, pod length, number of seeds per pod, dry pod weight, dry grain yield, 100-seed weight, dry fodder weight and total plant biomass. These parameters were evaluated from $2 \mathrm{~m}$ of the inner two rows of each plot.

Expreiment 2: Evaluation of 9 improved extraearly- and early-maturing cowpea varieties and a local check for intercropping with maize. This experiment was done in one location (Otobi) and for two seasons (April-early August and mid-AugustNovember), 2009. The experiment was a split-plot laid out in randomized complete block design with three replications. The main plot treatments were two cropping systems $\{(i)$ sole cropping-cowpea and maize (ii) intercropping-cowpea+maize\}.The sub-plot treatments were 10 cowpea varieties (9 improved and one local variety), grouped into two maturity classes discriminated by days to maturity. These included two extra-early-maturing varieties(ITOOK1217 and IT04K-221-1) and seven early-maturing varieties(IT03K-378-4,IT03K-316-1,IT99K-377-

1,IT98K-692,IT04K-217-5,IT03K-324-9,IT03K-351-

1). The local variety(Ife Brown), which is also an improved variety, had been classified as early(BNARDA,1999) but had been under cultivation in the locality(Otobi) for more than a decade. The improved varieties used in this study were selected from those used in Experiment 1.Their selection was based on yield performance and preference rating by farmers in Otobi who were involved in Experiment 1 from planting through to harvesting, threshing and winnowing. The maize variety used in the experiment was Striga-tolerant CY.TZL.comp.1c4 obtained from IITA, Ibadan, Nigeria. The land used for the experiment was ploughed three weeks before being harrowed once and ridged.
Cowpea and maize were sown either as sole crop or intercrop on ridges (which is the dominant practice used by farmers in Otobi). The ridges, spaced $100 \mathrm{~cm}$ apart (crest to crest) were $50 \mathrm{~cm}$ wide with a $50-\mathrm{cm}$ furrow spacing separating one from the other. Each sub-plot consisted of 4 ridges of $4 \mathrm{~m}$ length $\left(16 \mathrm{~m}^{2}\right)$ as gross plot. Cowpea was planted at the crest of the ridge, while maize was planted by the side as intercrop. All sole systems were formed at the crest of the ridge. Intercropping had a 1:1 (cowpea: maize) row proportion, such that one row of cowpea alternated with one row of maize. Intercrop plots had $50 \%$ of the full population of each of the component crops(100,000 plants/ha (cowpea) and 40,000 plants /ha (maize). Three seeds of each crop (cowpea or maize) were sown per hill and thinned to two plants per hill eight days after sowing as recommended by BNARDA(2003).All plots received a basal application of $30 \mathrm{~kg} \mathrm{~N}, 12.90 \mathrm{~kg} \mathrm{P}$ and $24.90 \mathrm{~kg} \mathrm{~K}$ per hectare, supplied as $200 \mathrm{~kg}$ NPK:15:15:15 compound fertilizer broadcast and incorporated before sowing of both crops on $3^{\text {rd }}$ May and $10^{\text {th }}$ August, 2009 , for the early season and late season planting, respectively. Sole and intercropped maize were top-dressed 4 WAP with $46 \mathrm{~kg} \mathrm{~N} /$ ha by manual operation. Two hoeweeding were done at 3 and 6 WAP for all plots. Insect pest control was carried out as done in Experiment 1. Harvesting, drying, threshing, winnowing as well as data collection for the cowpea component were effected as in Experiment 1.However, for the maize component, observations were made and recorded from the inner $2 \mathrm{~m} \times 2 \mathrm{~m}$ of each sub-plot for ear length, number of cobs per plant, cob length, cob weight, total plant biomass, grain yield, 100-seed weight and harvest index.Net returns were also worked out to evaluate the economics of the system.

Assessments of intercrop productivity were estimated as below:

1. Intercrop advantage was calculated by the determination of land equivalent ratio (LER) (Ofori and Stern, 1987).The LER, an accurate assessment of the biological efficiency of the intercropping situation, was calculated as:

LER $=($ Yab/Yaa $)+(Y b a / Y b b)$

Where $Y a a$ and $Y b b$ are yields as sole crops of $a$ and $b$ and $Y a b$ and $Y b a$ are yields as intercrops of $a$ and b. Values of LER greater than 1 are considered advantageous.

2. The relative dominance of one species over the other in this intercropping study was estimated by the 
use of relative crowding coefficient $(\mathrm{K})$ (Banik et al., 2006). K was calculated as:

$\mathbf{K}=(\mathbf{K}$ cowpea $\times \mathbf{K}$ maize $)$

Where,Kcowpea $=$ Yab $\times$ Z Za $/(\mathbf{Y a a - Y a b )} \times \mathbf{Z} a b$

Kmaize $=$ Y $b a \times \mathbf{Z} a b /(\mathbf{Y} b b-\mathbf{Y} b a) \times \mathbf{Z} b a$

where, Yab and Yba were the yields of cowpea and maize in the intercrop, respectively, $\mathrm{Yaa}$ and $\mathrm{Y} b b$ ,were the yields of cowpea and maize in sole crop, respectively and $\mathbf{Z a b}$ and $\mathbf{Z} b a$ were the respective proportions of cowpea and maize in the in the intercropping systems. When the value of $\mathrm{K}$ is greater than 1.00 , there is intercrop advantage; when $\mathrm{K}$ is equal to 1.00 , there is no yield advantage; and when $\mathrm{K}$ is less than 1.00 , there is a disadvantage.

3. Land equivalent coefficient (LEC), a measure of interaction concerned with the strength of relationship was calculated thus,

\section{$\mathrm{LEC}=\mathbf{L a} \times \mathbf{L} b$}

Where, $\mathrm{La}=\mathrm{LER}$ of main crop and $\mathrm{L} b=\mathrm{LER}$ of intercrop (Adetiloye et al.,1983).For a two-crop mixture the minimum expected productivity coefficient (PC) is $25 \%$,i.e. a yield advantage is obtained if LEC value exceeds 0.25 .

4. Area-Time equivalency ratio (ATER), the ratio of number of hectare-days required in monoculture to the number of hectare-days used in the intercrop to produce identical quantities of each of the components, was computed as:

$$
\text { ATER }=\frac{(\text { Rya } \times \mathrm{ta})+(\mathrm{Ry} b \mathrm{x} \text { t } b)}{\mathrm{T}}
$$

Where, Ry = Relative yield of species ' $a$ ' or ' $b$ ' i.e., yield of intercrop/yield of main crop, $t=$ duration (days) for species ' $a$ ' or 'b' and T = duration (days) of the intercropping system (Hiebisch and Mc Collum, 1987).

Competitive ratio $(\mathrm{CR})$ indicates the number of times by which one component crop is more competitive than the other. Relative species competition is often evaluated using competitive ratios (Putnam et al., 1984). This was calculated as :

$$
\mathbf{R a}=\mathbf{L} a / \mathbf{L} b \times \mathrm{zba} / z a b
$$

Where $\mathrm{Ra}$ is the competitive ratio of crop a and $\mathrm{La}$ and $L b$ are the LERs of crops $a$ and $b$ respectively, $z b a$ is the proportion of crop $a$ in the $a b$ intercrop and $z a b$ is the proportion of crop $b$ in the $a b$ intercrop. If
$\mathrm{Ra}<1$, there is a positive benefit and the crop can be grown in association; if $\mathrm{Ra}>1$, there a negative benefit. The reverse is true for $\mathrm{R} b$.

5. Aggressivity is another index that represents a simple measure of how much the relative yield increase in crop $a$ is greater that of crop $b$ in an intercropping system. It was calculated as:

$$
A a b=(\mathbf{Y a b} / \mathrm{YaaZ} a b)-(\mathbf{Y} b a / Y b b Z b a)
$$

Where $Y a a$ and $Y b b$ are yields as sole crops of $a$ and $b$ and $Y a b$ and $Y b a$ are yields as intercrops of $a$ and $b$.Zab and Zba are the sown proportions of $a$ and $b$, respectively.

If $A a b=0$, both crops are equally competitive; if $A a b$ is positive, $a$ is dominant; if Aab is negative, $a$ is the dominated crop (Ghosh et al., 2006).

Data collected following standard procedures were analyzed using GENSTAT Release 7.23 (2007), following standard analysis of variance procedures and least significant difference (LSD) test at $5 \%$ probability level was used to compare the treatment means. Also paired t-test was used to compare the means of the locations. It must be noted that data for each parameter measured for early and late planting in 2009 were pooled and analyzed because there was no significant effect between the sesons.

\section{RESULTS:}

Experiment 1.The rainfall in both locations of the work was considered adequate for crop growth and development.

Experiment 1: Results of days to $50 \%$ flowering, days to maturity, number of pods per plant and length of pods of cowpea grown under sole systems in Makurdi and Otobi in 2008 are presented in Table 1. Significant differences $(P \leq 0.05)$ existed between cowpea varieties in the number of days to $50 \%$ flowering and days to maturity in Makurdi and Otobi. Days to $50 \%$ flowering (DF) varied from 32.72 to 54.84 days after planting (DAP) with a mean of 44.31 DAP. IT00K-1217 and IT99K-530-1 flowered and matured earlier than all other cowpea varieties in both locations. Similar to the situation in DF, IT00K1217 and IT99K-530-1 matured earlier (46.72 and 53.84 DAP, respectively) than all the other cowpea varieties used in this study in both Makurdi and Otobi .The mean days to maturity for both locations was 65.62 DAP. The local check (Ife Brown) had the highest significant days to maturity (74.67 DAP). IT00K-1217 and IT99K-530-1, although flowered 
about the same time (within 33 DAP), IT00K-1217 matured significantly earlier (46.72 DAP) than IT99K530-1(53.84 DAP).Cowpea varieties generally flowered and matured earlier in Makurdi than in Otobi.

Significant differences ( $P \leq 0.05)$ were observed between cowpea varieties in the number of pods produced per plant (NP) and pod length(LP).NP varied between 4.00 and 18.00 (Makurdi) and 5.0018.00 (Otobi) with an average of 12.85 (Makurdi) and 13.34(Otobi).IT03K-316-1 had the highest NP in Makurdi,but this was not significantly different from
NP of several other varieties. In Otobi ,IT03K-221-1 gave the highest significant NP(18.00), but this was only comparable with the NP of IT03K-316-1(17.67) and IT00K-1217(17.44).ITO0K-1207 produced the least NP in both locations with a mean figure of 4.50 . NP in Otobi (13.34) was significantly higher than that of Makurdi(12.85).Pod length varied from 8.95 to 21.61 with a mean of 16.56 for both sites.IT04K-2175 had the longest pod $(21.61 \mathrm{~cm})$ in both locations, while ITOOK-1207 had the shortest pods (8.95 $\mathrm{cm})$. There was no significant difference in pod length between cowpea grown in Makurdi and Otobi.

Table 1: Days to $50 \%$ flowering(DF), days to maturity (DM),number of pods per plant (NP) and pod length(LP) of sole cowpea in Makurdi(Mkd) and Otobi in 2008.

\begin{tabular}{|c|c|c|c|c|c|c|c|c|c|c|c|c|}
\hline \multirow[b]{2}{*}{ Variety } & \multicolumn{3}{|c|}{ DF } & \multicolumn{3}{|c|}{ DM } & \multicolumn{3}{|c|}{ NP } & \multicolumn{3}{|c|}{ LP $(\mathrm{cm})$} \\
\hline & Mkd & Otobi & Mean & Mkd & Otobi & Mean & Mkd & Otobi & Mean & Mkd & Otobi & Mean \\
\hline IT03K-378-4 & 41.00 & 42.00 & 41.5 & 70.67 & 71.2 & 70.94 & 13.33 & 14.11 & 13.72 & 14.00 & 14.18 & 14.09 \\
\hline IT03K-316-1 & 45.00 & 45.33 & 45.17 & 71.33 & 72.11 & 71.72 & 18.00 & 17.67 & 17.84 & 17.00 & 17.33 & 17.17 \\
\hline IT00K-1207 & 54.33 & 55.11 & 54.72 & 66.33 & 65.67 & 66.00 & 4.00 & 5.00 & 4.50 & 9.00 & 8.89 & 8.95 \\
\hline IT98K-133-1-1 & 52.00 & 52.33 & 52.17 & 66.00 & 66.33 & 66.17 & 8.33 & 9.11 & 8.72 & 19.00 & 18.33 & 18.67 \\
\hline IT99K-377-1 & 44.00 & 43.67 & 43.84 & 66.00 & 67.00 & 66.5 & 8.00 & 8.33 & 8.17 & 16.00 & 15.67 & 15.84 \\
\hline IT99K-216-44 & 51.00 & 52.00 & 51.5 & 71.00 & 70.67 & 70.84 & 8.67 & 9.22 & 8.95 & 16.00 & 15.83 & 15.92 \\
\hline IT03K-324-9 & 42.33 & 42.44 & 42.39 & 65.33 & 66.11 & 65.72 & 13.67 & 14.22 & 13.94 & 20.00 & 20.33 & 20.17 \\
\hline IT03K-351-1 & 41.00 & 41.33 & 41.17 & 66.00 & 67.00 & 66.5 & 14.00 & 15.00 & 14.50 & 17.00 & 17.33 & 17.17 \\
\hline IT00K-1217 & 32.33 & 33.11 & 32.72 & 46.33 & 47.11 & 46.72 & 17.33 & 17.44 & 17.39 & 15.00 & 16.00 & 15.50 \\
\hline IT98K-692 & 40.67 & 41.89 & 41.28 & 66.33 & 65.78 & 66.06 & 15.67 & 16.22 & 15.95 & 17.00 & 17.89 & 17.45 \\
\hline IT04K-217-5 & 55.00 & 54.67 & 54.84 & 69.33 & 69.44 & 69.39 & 15.67 & 16.22 & 15.95 & 22.00 & 21.22 & 21.61 \\
\hline IT03K-369-3 & 42.00 & 42.33 & 42.17 & 66.00 & 66.33 & 66.17 & 13.00 & 14.00 & 13.50 & 16.00 & 16.40 & 16.20 \\
\hline IT04K-221-1 & 43.00 & 43.33 & 43.17 & 65.00 & 66.00 & 65.50 & 17.00 & 18.00 & 17.50 & 16.00 & 17.00 & 16.50 \\
\hline IT99K-530-1 & 33.00 & 32.67 & 32.84 & 53.00 & 54.67 & 53.84 & 17.00 & 16.67 & 16.84 & 17.00 & 16.83 & 16.92 \\
\hline $\begin{array}{l}\text { Ife } \\
\text { Brown(check) }\end{array}$ & 45.00 & 45.33 & 45.17 & 72.00 & 77.33 & 74.67 & 9.00 & 8.83 & 8.92 & 16.00 & 16.33 & 16.17 \\
\hline Mean & 44.11 & 44.50 & 44.31 & 65.38 & 65.85 & 65.62 & 12.85 & 13.34 & 13.10 & 16.47 & 16.64 & 16.56 \\
\hline FLSD(0.05) & 1.62 & 0.93 & & 2.13 & 1.16 & & 5.80 & 1.02 & & 2.52 & 1.04 & \\
\hline $\begin{array}{l}\text { Paired } \\
\text { test }(0.05) \\
\text { Mkd vs Otobi }\end{array}$ & $-3.08^{*}$ & & & $-2.22^{*}$ & & & $-4.00^{*}$ & & & $-1.20^{\text {ns }}$ & & \\
\hline
\end{tabular}

Significant differences were observed between cowpea varieties planted at Makurdi and Otobi for number of seeds per pod (NS), dry pod weight (DPY), dry grain yield (DGY), and total plant biomass (TPB) (Table 2).IT98K-133-1-1 had the highest NS values in Makurdi (18.00) and Otobi (17.00) but this was similar to NS values obtained by such varieties as IT04K-217-5 and IT98K-692 (15.00) in Makurdi only.IT00K-1207 gave the lowest significant NS in both locations with a mean of 7.84.Generally, the NS of cowpea in Makurdi and Otobi were not statistically different.
IT03K-369-3 produced the highest DPY(2.83 t/ha ) in Makurdi, but this was at par with DPY of such varieties as IT04K-221-1,IT03K-324-9,IT098K692,IT03K-316-1,IT04K-217-5,IT03K-351-1, IT99K-

530-1 and IT00K-1217. IT04K-221-1 gave the highest significant DPY value(2.93 t/ha) at Otobi and this was only similar to that produced by ITO3K-369-3(2.92 $\mathrm{t} / \mathrm{ha}$ ).All other varieties, including the local check gave lower values of DPY.IT00K-1207 produced the least DPY in both locations (0.43 t/ha and $0.48 \mathrm{t} / \mathrm{ha}$, in Makurdi and Otobi ,respectively).Mean DPY at 
Otobi (2.06 t/ha) was higher than that in Makurdi(1.92).

DGY varied from $0.22 \mathrm{t} /$ ha to $2.15 \mathrm{t} / \mathrm{ha}$ with a mean of $1.23 \mathrm{t} /$ ha for both locations. IT04K-221-1 produced the highest dry grain yield in Makurdi (2.04 t/ha) and Otobi $(2.26 \mathrm{t} / \mathrm{ha})$. However, other cowpea varieties with comparable DGY to IT04K-221-1 in Makurdi included: IT03K-324-9, IT98K-692 andIT00K-1217.In Otobi, no other variety of cowpea had comparable yield to IT04K-221-1. The variety with the lowest DGY in both locations was ITO0K-1207 with a mean DGY of $0.22 \mathrm{t} / \mathrm{ha}$ for both locations. Cowpeas in Otobi gave higher DGY (1.26 t/ha) than those in Makurdi (1.19t/ha).

TPB of cowpea varied from $3.10 \mathrm{t} / \mathrm{ha}$ to $5.09 \mathrm{t} / \mathrm{ha}$ with a mean value of $4.05 \mathrm{t} / \mathrm{ha}$ for both sites of the experiment .In Makurdi, the highest significant TPB was obtained from IT04K-217-5 (5.08 t/ha),but this was not significantly different from TPB of IT98K133-1-1, IT04K-221-1, IT03K-324-9, IT03K-316-1, IT98K-692, IT99K-377-1 and IT03K-351-1. In Otobi, IT04K-217-5 had the highest significant TPB (5.09 $\mathrm{t} / \mathrm{ha}$ ). Other varieties that gave good yield (above 4.00 $\mathrm{t} / \mathrm{ha}$ ) of TPB were the same as those observed in
Makurdi. There was no significant difference in TPB of cowpea between Makurdi and Otobi in 2008.

Table 3 presents the results of dry fodder weight (DFW) and 100-seed weight of cowpea varieties planted in Makurdin and Otobi in 2008.IT98K-133-1-1 had the highest DFW in both Makurdi(3.42 t/ha) and Otobi (3.51 t/ha).In both locations only IT00K-1207 cowpea gave a comparable DFW figure to IT98K133-1-1.All the other varieties had significantly lower DFW. IT99K-530-1 and IT00K-1217 gave the lowest significant DFW (1.25 t/ha) in both locations. The mean DFW in Otobi (2.18 t/ha) was higher than that in Makurdi (2.11 t/ha).

The 100-SW of IT04K-217-5(21.09 g) was significantly higher than all cowpea varieties in Makurdi location, except IT03K-324-9, IT03K-378-4 and IT99K-216-44.In Otobi location, the result was similar, except that no other variety of cowpea had statistically comparable 100-SW figure with IT04K217-5. ITOOK-1207 gave the least $100-S W$ value in both locations. There was no significant difference in 100-SW between cowpea varieties planted in Makurdi and Otobi in 2008.

Table 2: Number of seeds per pod (NS), dry pod weight (DPY), dry grain yield (DGY) and total plant biomass (TPB) of sole cowpea in Makurdi and Otobi in 2008.

\begin{tabular}{|c|c|c|c|c|c|c|c|c|c|c|c|c|}
\hline \multirow[b]{2}{*}{ Variety } & \multicolumn{3}{|c|}{ NS } & \multicolumn{3}{|c|}{ DPY (t/ha) } & \multicolumn{3}{|c|}{ DGY (t/ha) } & \multicolumn{3}{|c|}{ TPB (t/ha) } \\
\hline & Mkd & Otobi & Mean & Mkd & Otobi & Mean & Mkd & Otobi & Mean & Mkd & Otobi & Mean \\
\hline IT03K-378-4 & 13.00 & 12.67 & 12.84 & 1.67 & 1.78 & 1.73 & 1.15 & 1.18 & 1.17 & 3.82 & 3.86 & 3.84 \\
\hline IT03K-316-1 & 14.00 & 13.00 & 13.50 & 2.63 & 2.74 & 2.69 & 1.82 & 1.91 & 1.87 & 4.28 & 4.39 & 4.34 \\
\hline IT00K-1207 & 8.00 & 7.67 & 7.84 & 0.43 & 0.48 & 0.46 & 0.17 & 0.27 & 0.22 & 3.58 & 3.41 & 3.50 \\
\hline IT98K-133-1-1 & 18.00 & 17.00 & 17.50 & 1.52 & 1.57 & 1.55 & 0.78 & 0.88 & 0.79 & 4.92 & 4.89 & 4.91 \\
\hline IT99K-377-1 & 14.00 & 13.67 & 13.84 & 1.30 & 1.41 & 1.36 & 0.70 & 0.77 & 0.74 & 4.34 & 4.44 & 4.39 \\
\hline IT99K-216-44 & 11.00 & 10.67 & 10.83 & 0.87 & 0.89 & 0.88 & 0.43 & 0.48 & .46 & 3.06 & 3.13 & 3.10 \\
\hline IT03K-324-9 & 14.00 & 13.67 & 13.84 & 2.74 & 2.87 & 2.81 & 1.73 & 1.79 & 1.76 & 4.48 & 4.49 & 4.48 \\
\hline IT03K-351-1 & 13.00 & 14.00 & 13.50 & 2.36 & 2.46 & 2.41 & 1.31 & 1.36 & 1.34 & 4.25 & 4.31 & 4.28 \\
\hline IT00K-1217 & 11.00 & 12.00 & 11.50 & 2.14 & 2.24 & 2.19 & 1.57 & 1.67 & 1.62 & 3.35 & 3.39 & 3.37 \\
\hline IT98K-692 & 15.00 & 14.00 & 14.50 & 2.71 & 2.87 & 2.79 & 1.81 & 1.88 & 1.84 & 4.34 & 4.39 & 4.37 \\
\hline IT04K-217-5 & 15.00 & 15.33 & 15.17 & 2.51 & 2.64 & 2.58 & 1.60 & 1.65 & 1.63 & 5.08 & 5.09 & 5.09 \\
\hline IT03K-369-3 & 13.00 & 13.00 & 13.00 & 2.83 & 2.92 & 2.88 & 0.89 & 0.92 & 0.91 & 3.84 & 3.88 & 3.86 \\
\hline IT04K-221-1 & 14.00 & 14.33 & 14.17 & 2.80 & 2.93 & 2.87 & 2.04 & 2.26 & 2.15 & 4.44 & 4.48 & 4.46 \\
\hline IT99K-530-1 & 14.00 & 15.00 & 14.50 & 2.37 & 2.27 & 2.32 & 1.26 & 1.31 & 1.29 & 3.59 & 3.62 & 3.61 \\
\hline $\begin{array}{l}\text { Ife } \\
\text { Brown(check) }\end{array}$ & 12.00 & 12.33 & 12.17 & 0.88 & 0.91 & 0.90 & 0.55 & 0.61 & 0.58 & 3.04 & 3.15 & 3.10 \\
\hline Mean & 13.27 & 13.22 & 13.25 & 1.92 & 2.06 & 1.99 & 1.19 & 1.26 & 1.23 & 4.03 & 4.06 & 4.05 \\
\hline$\overline{F L S D}(0.05)$ & 3.34 & 1.31 & & 0.82 & 0.10 & & 0.60 & 0.07 & & 1.00 & 0.12 & \\
\hline $\begin{array}{l}\text { Paired- } \\
\text { test }(0.05) \\
\text { (Mkd vs Otobi) }\end{array}$ & $0.24^{\mathrm{ns}}$ & & & -4.90 & & & -6.28 & & & -1.93 & & \\
\hline
\end{tabular}


Agric. Biol. J. N. Am., 2010, 1(5): 845-858

Table 3: Dry fodder weight (DFW),100-seed weight (100-SW) of sole cowpea in Makurdi and Otobi in 2008.

\begin{tabular}{|c|c|c|c|c|c|c|}
\hline \multirow[b]{2}{*}{ Variety } & \multicolumn{3}{|c|}{ DFW (t/ha) } & \multicolumn{3}{|c|}{ 100-SW (g) } \\
\hline & Mkd & Otobi & Mean & Mkd & Otobi & Mean \\
\hline IT03K-378-4 & 2.15 & 2.18 & 2.17 & 18.51 & 17.89 & 18.20 \\
\hline IT03K-316-1 & 1.67 & 1.74 & 1.71 & 17.12 & 16.49 & 16.81 \\
\hline IT00K-1207 & 3.17 & 3.28 & 3.23 & 7.04 & 7.73 & 7.39 \\
\hline IT98K-133-1-1 & 3.42 & 3.51 & 3.47 & 12.42 & 12.39 & 12.41 \\
\hline IT99K-377-1 & 3.04 & 3.08 & 3.06 & 11.39 & 12.39 & 11.89 \\
\hline IT99K-216-44 & 2.19 & 2.22 & 2.21 & 18.39 & 18.49 & 18.44 \\
\hline IT03K-324-9 & 1.74 & 1.81 & 1.78 & 19.82 & 19.89 & 19.86 \\
\hline IT03K-351-1 & 1.89 & 1.92 & 1.91 & 18.57 & 18.67 & 18.62 \\
\hline IT00K-1217 & 1.21 & 1.29 & 1.25 & 13.06 & 13.75 & 13.41 \\
\hline IT98K-692 & 1.63 & 1.65 & 1.64 & 14.52 & 14.59 & 14.56 \\
\hline IT04K-217-5 & 2.53 & 2.60 & 2.57 & 21.09 & 21.69 & 21.39 \\
\hline IT03K-369-3 & 2.01 & 2.07 & 2.04 & 15.37 & 15.61 & 15.49 \\
\hline IT04K-221-1 & 1.65 & 1.69 & 1.67 & 15.02 & 15.26 & 15.14 \\
\hline IT99K-530-1 & 1.22 & 1.27 & 1.25 & 12.74 & 12.72 & 12.73 \\
\hline Ife Brown(check) & 2.17 & 2.32 & 2.25 & 16.82 & 16.90 & 16.86 \\
\hline Mean & 2.11 & 2.18 & 2.15 & 15.45 & 15.64 & 15.55 \\
\hline FLSD(0.05) & 0.37 & 0.06 & & 3.13 & 0.06 & \\
\hline $\begin{array}{l}\text { Paired-test(0.05)(Mkd vs } \\
\text { Otobi) }\end{array}$ & \multicolumn{3}{|l|}{$-6.91^{*}$} & \multicolumn{3}{|c|}{$-1.49^{\mathrm{ns}}$} \\
\hline
\end{tabular}

Table 4:Effect of cropping system with variety on days to flowering (DF),days to maturity (DM) and number of branches per plant (BR) of extra-early- and early-maturing cowpea intercropped with maize at Otobi .

\begin{tabular}{|c|c|c|c|c|c|c|c|c|c|}
\hline & DF & & & DM & & & BR & & \\
\hline Variety & Sole & Intercrop & Mean & Sole & Intercrop & Mean & Sole & Intercrop & Mean \\
\hline IT03K-378-4 & 48.67 & 46.67 & 47.67 & 75.00 & 75.33 & 75.17 & 4.33 & 2.33 & 3.33 \\
\hline IT03K-316-1 & 46.33 & 44.67 & 45.50 & 76.33 & 76.00 & 76.17 & 4.32 & 4.00 & 4.17 \\
\hline IT99K-377-1 & 45.00 & 46.67 & 45.84 & 76.33 & 77.00 & 76.67 & 4.00 & 4.00 & 4.00 \\
\hline IT00K1217 & 37.67 & 38.33 & 38.00 & 58.67 & 59.33 & 59.00 & 2.33 & 1.67 & 2.00 \\
\hline IT98K-692 & 45.00 & 45.00 & 45.00 & 76.67 & 75.00 & 75.84 & 3.67 & 3.00 & 3.17 \\
\hline IT04K-217-5 & 46.33 & 46.00 & 46.17 & 76.33 & 75.67 & 76.00 & 4.00 & 3.00 & 3.50 \\
\hline IT04K-221-1 & 44.33 & 44.33 & 44.33 & 62.67 & 68.00 & 65.34 & 3.00 & 3.00 & 3.00 \\
\hline IT03K-324-9 & 45.00 & 45.00 & 45.00 & 75.00 & 73.33 & 74.17 & 4.00 & 3.00 & 3.50 \\
\hline IT03K-351-1 & 46.00 & 45.00 & 45.50 & 75.00 & 75.33 & 75.17 & 5.00 & 4.67 & 4.84 \\
\hline Ife Brown(check) & 45.67 & 45.00 & 45.34 & 76.00 & 77.33 & 76.67 & 3.00 & 4.33 & 3.67 \\
\hline Mean & 45.00 & 44.67 & 44.83 & 72.80 & 73.23 & 73.23 & 3.77 & 3.30 & 3.53 \\
\hline FLSD(0.05) & & & & & & & & & \\
\hline CS & NS & & & NS & & & 0.40 & & \\
\hline VAR & 1.38 & & & 2.27 & & & 0.89 & & \\
\hline CS $\times$ VAR & NS & & & NS & & & NS & & \\
\hline
\end{tabular}

CS:cropping system

VAR:variety

NS:not significant at $5 \%$ probability level. 
Agric. Biol. J. N. Am., 2010, 1(5): 845-858

Table 5: Influence of cropping system with variety on the number of pods per plant (NP),pod length (LP) (cm) and number of seeds per pod of extra-early- and early-maturing cowpea intercropped with maize at Otobi.

\begin{tabular}{|c|c|c|c|c|c|c|c|c|c|}
\hline & \multicolumn{3}{|c|}{ NP } & \multicolumn{3}{|c|}{ LP } & \multicolumn{3}{|c|}{ NS } \\
\hline Variety & Sole & Intercrop & Mean & Sole & Intercrop & Mean & Sole & Intercrop & Mean \\
\hline IT03K-378-4 & 16.67 & 14.67 & 15.67 & 12.00 & 13.87 & 12.94 & 13.33 & 11.00 & 12.17 \\
\hline IT03K-316-1 & 15.33 & 14.00 & 14.67 & 15.30 & 15.07 & 15.19 & 12.33 & 13.67 & 13.00 \\
\hline IT99K-377-1 & 13.33 & 17.00 & 15.17 & 15.97 & 21.40 & 18.69 & 13.67 & 15.00 & 14.34 \\
\hline IT00K1217 & 14.00 & 11.67 & 12.84 & 22.33 & 19.93 & 21.13 & 12.67 & 15.00 & 13.84 \\
\hline IT98K-692 & 17.33 & 20.33 & 18.82 & 23.83 & 17.63 & 20.73 & 12.33 & 13.67 & 13.00 \\
\hline IT04K-217-5 & 22.000 & 17.33 & 19.67 & 22.37 & 16.27 & 19.32 & 15.00 & 16.67 & 15.84 \\
\hline IT04K-221-1 & 17.67 & 18.33 & 18.00 & 14.50 & 15.37 & 14.94 & 11.33 & 12.00 & 11.67 \\
\hline IT03K-324-9 & 14.00 & 15.00 & 14.50 & 20.40 & 18.37 & 19.39 & 12.67 & 16.00 & 13.84 \\
\hline IT03K-351-1 & 22.67 & 19.00 & 20.84 & 19.20 & 20.77 & 19.99 & 10.33 & 10.33 & 10.33 \\
\hline Ife Brown(check) & 20.00 & 26.00 & 23.00 & 22.97 & 16.00 & 19.49 & 13.33 & 13.67 & 13.50 \\
\hline Mean & 17.30 & 17.33 & 17.32 & 18.89 & 17.47 & 18.18 & 12.70 & 13.70 & 13.20 \\
\hline FLSD(0.05) & & & & & & & & & \\
\hline CS & NS & & & NS & & & NS & & \\
\hline VAR & NS & & & NS & & & NS & & \\
\hline CS x VAR & NS & & & NS & & & NS & & \\
\hline
\end{tabular}

CS:cropping system

VAR:variety

NS:not significant at $5 \%$ probability level.

Table 6: Effect of cropping system with variety on grain yield (GY) and one-hundred seed weight(100-SW) of extraearly- and early-maturing cowpea varieties intercropped with maize at Otobi.

\begin{tabular}{|c|c|c|c|c|c|c|}
\hline & \multicolumn{3}{|c|}{ GY } & \multicolumn{3}{|c|}{ 100-SW } \\
\hline Variety & Sole & Intercrop & Mean & Sole & Intercrop & Mean \\
\hline IT03K-378-4 & 1.21 & 0.54 & 0.88 & 16.72 & 15.41 & 16.07 \\
\hline IT03K-316-1 & 1.24 & 0.85 & 1.05 & 14.65 & 16.35 & 15.50 \\
\hline IT99K-377-1 & 1.37 & 0.70 & 1.04 & 12.57 & 12.73 & 12.65 \\
\hline IT00K1217 & 0.99 & 0.71 & 0.85 & 11.01 & 11.65 & 11.33 \\
\hline IT98K-692 & 1.74 & 0.90 & 1.32 & 13.16 & 11.73 & 12.45 \\
\hline IT04K-217-5 & 1.37 & 0.91 & 1.14 & 17.50 & 18.30 & 17.90 \\
\hline IT04K-221-1 & 1.37 & 1.12 & 1.25 & 15.27 & 14.57 & 14.92 \\
\hline IT03K-324-9 & 1.68 & 1.07 & 1.38 & 17.41 & 17.67 & 17.54 \\
\hline IT03K-351-1 & 1.76 & 0.65 & 1.21 & 15.48 & 16.58 & 16.08 \\
\hline Ife Brown(check) & 1.28 & 0.69 & 0.99 & 16.34 & 14.00 & 15.17 \\
\hline Mean & 1.40 & 0.82 & 1.11 & 15.01 & 14.90 & 14.96 \\
\hline \multicolumn{7}{|l|}{ FLSD(0.05) } \\
\hline $\mathrm{CS}$ & 0.24 & & & NS & & \\
\hline VAR & NS & & & 1.80 & & \\
\hline CS x VAR & NS & & & NS & & \\
\hline
\end{tabular}

CS:cropping system

VAR:variety

NS:not significant at $5 \%$ probability level. 


\section{Experiment 2:}

The interaction effects of cropping systems with variety on days to $50 \%$ flowering, days to maturity and number of branches per plant of extra-early- and early-maturing cowpea varieties intercropped with maize at Otobi were not significant $(P \geq 0.05)$, but the main effect of variety was (Table 4).The main effect of cropping system was only significant for the number of branches per plant of cowpea.

Days to $50 \%$ flowering of cowpea varied between 38.00 and 47.67 DAP with a mean of 44.83 , and days to maturity varied from 59.33-77.33 DAP with an average of 72.80 .

While IT00K-1217 flowered earlier than all the other cowpea varieties including the local check, it also, along with IT04K-221-1 matured earlier, irrespective of the cropping system adopted.

Sole cowpea produced significantly higher number of branches per plant than intercropped cowpea, except for IT99K-377-1 and IT04K-221-1, which had no depression in branching. Ife Brown recorded an increase in the number of branches per plant when intercropped.

The interaction effects of cropping systems with variety ,the main effects of cropping systems and variety on the number of pods per plant, pod length and number of seeds per pod of extra-early- and early- maturing cowpea varieties intercropped with maize at Otobi were not significant $(P \geq 0.05)$ (Table 5). Intercropping depressed the grain yields of extra-early- and early-maturing cowpea varieties grown with maize at Otobi (Table 6).While cowpea varieties yielded between $0.99 \mathrm{t} / \mathrm{ha}$ to $1.74 \mathrm{t} / \mathrm{ha}$ in sole systems, grain yield of cowpea varied between $0.54 \mathrm{t} /$ ha to $1.22 \mathrm{t} / \mathrm{ha}$ under intercropping.IT98K-692 produced the highest sole crop yield(1.74 t/ha) of cowpea, and IT00K-1217 gave the least (0.99 t/ha). Under intercropping environment,IT04K-221-1 had the highest grain yield(1.12 t/ha), whereas IT03K378-4 produced the lowest yield $(0.54 \mathrm{t} / \mathrm{ha})$. Percentage yield reductions varied from $10.95 \%$ in IT04K-221-1 to $63.07 \%$ (IT03K-351-1) with a mean of $40.23 \%$. The local check had a mean yield reduction of $46.09 \%$ and gave only $0.69 \mathrm{t} / \mathrm{ha}$ of grain under intercropping.(Table 6).

One-hundred seed weight varied with the cowpea variety(Table 6).IT04K-217-5 had the highest significant $100-\mathrm{SW}(17.50 \mathrm{~g}$ (sole) $18.30 \mathrm{~g}$ (intercrop) ),irrespective of the cropping system used .However this was not significantly different from 100-SW obtained by IT03K-324-9. IT00K1217 produced the least 100-SW (11.33 g).

Intercropped maize with IT03K-324-9 gave the tallest plant $(1.99 \mathrm{~m})$, although this was not significantly different from the plant height of sole maize $(1.92 \mathrm{~m})$ (Table7). Intercropped maize with IT03K-316-1 produced the shortest plant $(1.18 \mathrm{~m})$.Compared to sole cropped maize, intercropping did not reduce plant height of maize, except in maize combined with IT03K-316-1 and IT98K-692.

Intercropping maize with cowpea resulted in significant decreases in ear length, cob length, dry cob weight, dry grain yield and dry total plant biomass, but no significant effect was observed for harvest index (Table 7). Ear length (EL) of maize in this study varied from $18.49 \mathrm{~cm}$ to $36.33 \mathrm{~cm}$, with a mean of $27.84 \mathrm{~cm}$.All intercropped maize gave significantly shorter EL than the sole maize, except maize intercropped with IT03K-378-4(32.57 cm).

Sole cropped maize produced the longest cob (16.88 $\mathrm{cm}$ ), but this was only significantly greater than the cob length $(\mathrm{CL})$ of maize intercropped with such cowpea varieties as IT03K-378-4, IT04K-221-1, IT03K-316-1 and IT04K-217-5.

The highest significant dry cob weight (DCW) of maize (3.05 t/ha) was obtained under sole cropping. DCW of maize under intercropping varied from 1.08 t/ha (in IT00K-1217) to 2.03 t/ha (in IT03K-324-9) with a mean of $1.72 \mathrm{t} / \mathrm{ha}$. This represented a yield depression of $33.44 \%$ to $64.59 \%$ with a mean of $43.61 \%$ when compared to sole cropping. Similarly, sole maize gave significantly higher dry grain yield(GRY) than maize intercropped with all the cowpea varieties tested(Table 7).Grain yield reductions under intercropping as compared to sole maize varied from $49.26 \%$ to $72.41 \%$.In intercropping, maize combined with IT03K-351-1 gave the highest grain yield(1.03 $\mathrm{t} / \mathrm{ha})$, while that combined with IT03K-324-9 gave the lowest yield (0.56 t/ha).Also, sole maize produced the highest significant total plant biomass (TB) (3.97 t/ha).Among the intercrop treatments, maize mixed with IT03K324-9 produced the highest TB (2.58 t/ha), while maize in ITOOK-1217 gave the lowest TB(1.37 $\mathrm{t} / \mathrm{ha}$ ). The mean TB value was $2.29 \mathrm{t} / \mathrm{ha}$.

There were no significant differences between the various treatments in the harvest index $(\mathrm{HI})$ and onehundred seed weight (100-SW) of maize obtained in this study. 
Table 7: Plant height (HGT)(m), ear length $(E L)(\mathrm{cm})$, cob length $(\mathrm{CL})(\mathrm{cm})$, dry cob $\quad$ weight $\quad$ (DCW) (t/ha), grain yield(GRY)(t/ha), total plant biomass(TB)(t/ha) and harvest ndex(HI)of maize intercropped with extra-early- and earlymaturing cowpea varieties at Otobi

\begin{tabular}{|l|l|l|l|l|l|l|l|l|}
\hline Cropping system & HGT & EL & CL & DCW & GRY & TB & $100-S W$ & HI \\
\hline Sole maize & 1.92 & 36.33 & 16.88 & 3.05 & 2.03 & 3.97 & 30.33 & 0.50 \\
\hline Maize in IT03K-378-4 & 1.55 & 32.57 & 11.87 & 1.74 & 0.81 & 1.85 & 30.50 & 0.42 \\
\hline Maize in IT03K-316-1 & 1.18 & 18.55 & 12.37 & 1.85 & 0.90 & 2.22 & 31.33 & 0.42 \\
\hline Maize in IT99K-377-1 & 1.66 & 26.35 & 13.97 & 1.79 & 0.89 & 2.30 & 30.67 & 0.39 \\
\hline Maize in IT00K1217 & 1.43 & 30.19 & 12.58 & 1.08 & 0.86 & 1.37 & 31.87 & 0.21 \\
\hline Maize in IT98K-692 & 1.35 & 29.19 & 13.88 & 1.81 & 1.02 & 2.32 & 33.09 & 0.48 \\
\hline Maize in IT04K-217-5 & 1.62 & 29.50 & 9.38 & 1.61 & 0.57 & 1.88 & 30.67 & 0.61 \\
\hline Maize in IT04K-221-1 & 1.61 & 18.49 & 12.03 & 1.83 & 0.98 & 2.32 & 30.00 & 0.44 \\
\hline Maize in IT03K-324-9 & 1.99 & 27.00 & 11.68 & 2.03 & 0.56 & 2.58 & 32.27 & 0.30 \\
\hline Maize in IT03K-351-1 & 1.49 & 30.81 & 15.03 & 1.80 & 1.03 & 2.16 & 32.00 & 0.42 \\
\hline Maize in Ife Brown(check) & 1.69 & 27.30 & 14.35 & 1.70 & 0.96 & 2.21 & 30.93 & 0.43 \\
\hline Mean & 1.59 & 27.84 & 13.09 & 1.85 & 0.97 & 2.29 & 31.24 & 0.42 \\
\hline FLSD(0.05) & & & & & & & & \\
\end{tabular}

NS:not significant at $5 \%$ probability level.

Table 8 presents the results of land equivalent ratio(LER), area $x$ time equivalency ratio (ATER), land equivalent coefficient (LEC), relative crowding coefficient of cowpea ( $\mathrm{K}$ cow), relative crowding coefficient of maize ( $\mathrm{K} \mathrm{ma}$ ), relative crowding coefficient of both components $(\mathrm{K})$,competitive ratio of cowpea (CR cow), competitive ratio of maize (CR ma), aggressivity of cowpea (AGG. Cow) and the aggressivity of maize component (AGG. Ma).

Only the intercrop treatments involving IT03K-316-1, IT03K-324-9, IT00K-1217, IT04K-217-5 and IT03K221-1 had LER values above 1.00. All other treatments including the local check (Ife Brown), produced lower LER values.IT03K-221-1intercropped with maize gave the highest LER value (1.46), while IT03K-378-4 combined with maize gave the least (0.86). Two varieties of cowpea (IT03K-221-1 and IT03K-316-1) intercropped with maize had ATER figure beyond 1.00,all others did not. IT03K-221-1 had the highest ATER (1.22), while IT03K-378-4 had the least (0.78). LEC values ranged from 0.18 to 0.52 with a mean of 0.27 . Cowpea varieties (IT03K-221-1, IT03K-316-1, IT03K-324-9 and IT03K-351-1) intercropped with maize gave LEC values beyond 0.25 ; all others including the local check did not. IT03K-221-1 combined with maize had the highest LEC figure (0.52) and IT03K-378-4 mixed with maize had the lowest (0.18).

While $K$ ma values were consistently positive, $K$ cow values were negative for some of the cowpea varieties (IT00K-1217 and IT04K-217-5).Several cowpea varieties had $K$ cow above 1.0 (IT03K-316-1, IT99K-377-1, IT98K-692, IT04K-221-1, IT03K-324-9 and Ife Brown),but maize combined with only a few cowpea varieties gave $K$ ma figures beyond 1.0 (IT98K-692, IT04K-221-1 and IT03K-351-1).Results of relative crowding coefficient for both intercrop components $(K)$ showed that only the combination of IT03K-316-1 and Ife Brown produced a value above 1.0.Negative $K$ values were recorded for such varieties as IT00K1217, IT04K-217-5 and IT04K-2211.

Competitive ratio figures for cowpea (CR cow) was consistently higher than competitive ratio values for maize (CR ma),except in such cases as IT98K-692 and Ife Brown intercropped with maize where the CR values were at par .Although no significant differences were observed between cowpea varieties in CR, significant differences were recorded between maize intercropped with cowpea. CR ma of IT03K351-1 was highest, but it was only significantly higher than the CR ma of IT03K-316-1, ITOOK1217 and IT04K-221-1.

Aggressivity of cowpea varieties (AGG.cow) was generally positive, while that of the maize (AGG.ma) was negative, except in the intercropping systems involving IT99K-377-1and IT03K-351-1, where the reverse was the case. 
Table 8: Land equivalent ratio(LER),area-time equivalent ratio (ATER),land equivalent coefficient (LEC), relative crowding coefficient of cowpea $(K$ cow),relative crowding coefficient of maize $(K \mathrm{ma})$, relative crowding coefficient of both component crops (K),competitive ratio of cowpea (CR cow), competitive ratio of maize (CRma),aggressivity of cowpea (AGG.cow) and aggressivity of maize(AGG.ma) of extra- early- and early-maturing cowpea varieties intercropped with maize at Otobi.

\begin{tabular}{|l|l|l|l|l|l|l|l|l|l|l|}
\hline $\begin{array}{l}\text { Cowpea } \\
\text { variety }\end{array}$ & LER & ATER & LEC & K cow & K ma & K & CR cow & CR ma & AGG.cow & AGG. ma \\
\hline IT03K-378-4 & 0.86 & 0.78 & 0.18 & 0.80 & 0.83 & 0.70 & 1.13 & 0.93 & 0.020 & -0.020 \\
\hline IT03K-316-1 & 1.13 & 1.02 & 0.31 & 2.3 & 0.83 & 1.93 & 1.53 & 0.67 & 0.120 & -0.120 \\
\hline IT99K-377-1 & 0.96 & 0.89 & 0.23 & 1.00 & 0.91 & 0.89 & 1.17 & 0.92 & -2.280 & 0.030 \\
\hline IT00K1217 & 1.09 & 0.81 & 0.24 & -0.50 & 0.85 & -1.17 & 2.71 & 0.45 & 0.260 & -0.260 \\
\hline IT98K-692 & 0.99 & 0.90 & 0.23 & 1.20 & 1.75 & 1.01 & 1.11 & 1.15 & 0.003 & -0.003 \\
\hline IT04K-217-5 & 1.07 & 0.94 & 0.23 & -2.0 & 0.39 & -0.73 & 2.68 & 0.43 & 0.240 & -0.240 \\
\hline IT04K-221-1 & 1.46 & 1.22 & 0.52 & 1.20 & 1.07 & -0.25 & 1.76 & 0.62 & 0.210 & -0.210 \\
\hline IT03K-324-9 & 1.08 & 0.96 & 0.28 & 1.9 & 0.40 & 0.71 & 1.53 & 0.73 & 0.100 & -0.040 \\
\hline IT03K-351-1 & 0.96 & 0.88 & 0.27 & 0.70 & 1.18 & 0.98 & 0.80 & 1.26 & -0.050 & 0.050 \\
\hline $\begin{array}{l}\text { Ife } \\
\text { Brown(check) }\end{array}$ & 0.97 & 0.90 & 0.23 & 11.80 & 0.96 & 8.39 & 1.07 & 1.14 & 0.007 & -0.007 \\
\hline Mean & 1.06 & 0.93 & 0.27 & 1.90 & 0.92 & 1.25 & 1.55 & 0.83 & -2.220 & -0.090 \\
\hline FLSD(0.05) & NS & NS & NS & NS & NS & NS & NS & 0.54 & NS & NS \\
\hline
\end{tabular}

NS:not significant at $5 \%$ probability level.

Most cowpea varieties gave negative net benefit values in sole cropping systems, but had positive net benefits under intercropping (Table 9). Sole cowpea had a mean net benefit of $-\mathrm{N} 560.00 / \mathrm{ha}$, while intercropped cowpea gave a mean value of $\mathrm{N}$ 11330.00/ha.Only IT98K-692, IT03K-324-9 and IT03K-351-1 produced positive net benefits in sole cowpea systems. Under intercropping, IT03K-378-4, IT99K-377-1, IT03K-351-1, IT03K-351-1 and Ife Brown (check) produced negative net benefits. Sole Table 9: Net benefits ( N/ha) of extra-early- and early-maturing cowpea varieties intercropped with maize at Otobi.

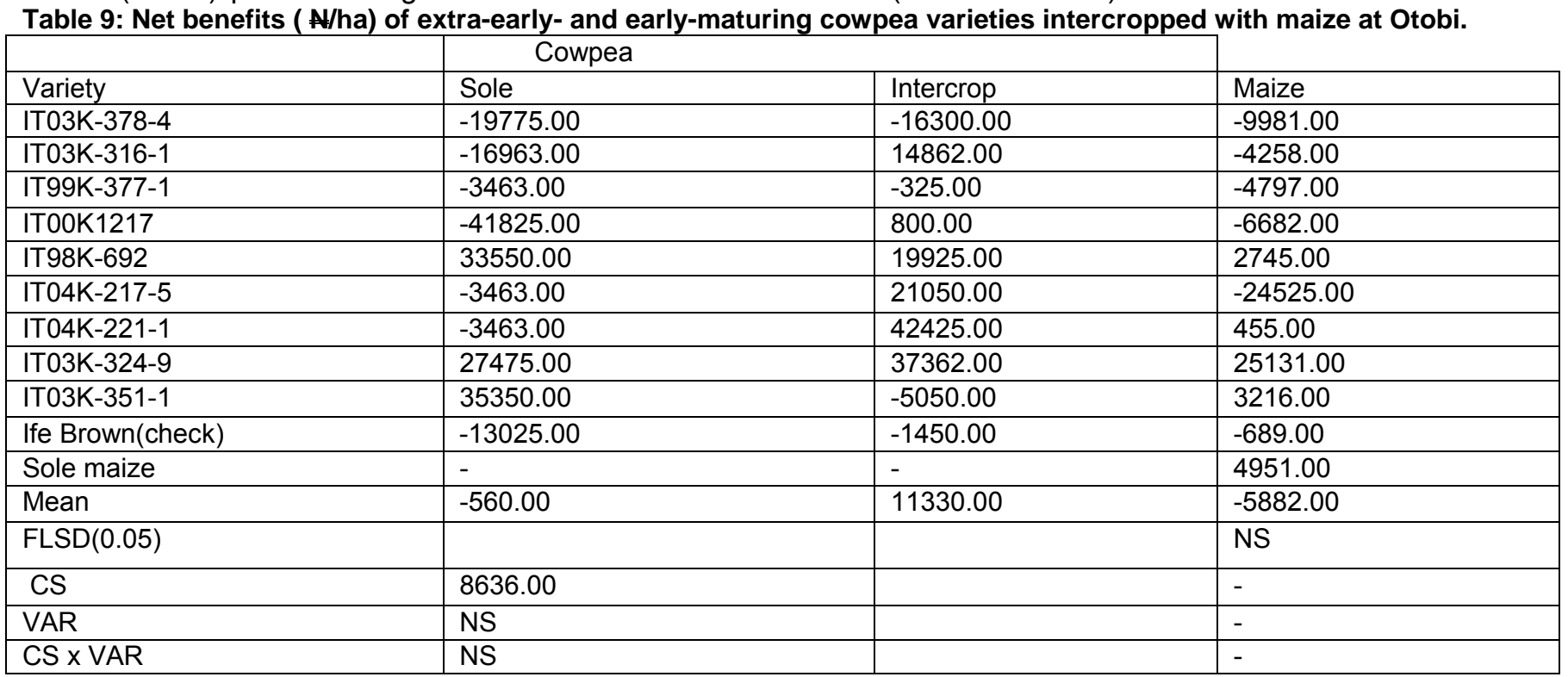

CS:cropping system

VAR:variety

NS:not significant at $5 \%$ probability level.

maize had a positive net benefit figure of $\mathrm{N}$ 4951.00/ha, but under intercrop environment, only maize associated with IT98K-692, IT04K-221-1, IT03K-324-9 and IT03K-351-1 gave positive net benefits. In sole crop systems, IT03K-351-1 had the highest net benefit ( $\$ 35350.00 / h a)$, while IT00K1217 gave the least net benefit ( $\mathrm{A} 41825.00 / \mathrm{ha}$ ). Intercropped IT04K-221-1 produced the largest net benefit ( $A 2425.00 / \mathrm{ha}$ ), while IT03K-378-4 gave the lowest (-N 16300.00/ha) 
Agric. Biol. J. N. Am., 2010, 1(5): 845-858

DISCUSSION: The fourteen improved cowpea varieties and the local check matured within 46.72 65.62 DAP. Singh et al. (2007) and Dugje et al. (2009) had classified cowpea varieties that matured in $\leq 60$ days as extra- early, 61-80 days (early) and > 80 days as late. Therefore, IT00K-1217 and IT99K$530-1$ could be classified as extra-early in both locations. However, IT04K-221-1 which had hitherto been classified as extra-early may be regrouped as early since it matured in 65.50 days in both locations of the experiment. This variety (IT04K-221-1) had a similar response under intercropping at Otobi and matured in 65.34 days. Singh et al. (1997) opined that extra-early varieties have opened the possibility of successful sole cropping in areas with short rainy season, double/triple cropping in areas with relatively longer rainfall, in relay cropping after millet, sorghum or maize as well as parallel multiple cropping with cassava and yam. Therefore, farmers could grow any of these varieties up to two or three times in Makurdi and Otobi. Although the local check had similar days to maturity with such other varieties as IT04K-221-1, IT03K-316-1, IT03K-324-9, IT03K-351-1 and IT98K692 , it gave significantly lower pod length, number of pods per plant and number of seeds per pod than these varieties, especially in Otobi location. These results may have culminated in the superior performance of these varieties (IT04K-221-1, IT03K316-1,IT03K-324-9,IT03K-351-1,IT00K-1217 and IT98K-692) and a few others over the local check in the dry pod and grain yields, but not in 100SW.Ajibade and Morakinyo (1999) and Attah (2002) stated that yield of cowpea was largely a function of pod length, number of pods per plant and number of seeds per pod.

IT04K-221-1 cowpea produced the highest mean dry grain yield of $2.15 \mathrm{t} / \mathrm{ha}$ for both locations, representing a $370.69 \%$ increase over the local check. This yield figure, though not significantly different from those obtained by IT03K-316-1, IT98K692, IT03K-324-9, IT04K-217-5 and IT00K-1217, was the only one that exceeded 2.0t/ha in both locations. It was also superior to that reported for IT93K-4521 (a very popular early-maturing cowpea also developed by IITA). Singh et al (2007) had indicated that IT93K-452-1 gave an average yield of $1.088 \mathrm{t} / \mathrm{ha}$ in 60-63 DAP. Dugje et al. (2009) had opined that the choice of any variety suitable for an agro-ecological zone should be based on the maturity period and yield potentials, among other considerations. The results obtained in this work suggested that IT04K-221-1 and such other varieties as IT03K-3161, IT98K-692, IT03K-324-9, IT04K-217-5 and IT00K-
1217 could be viewed as superior to the local check and therefore considered as better choices, especially at Otobi for further investigations.

Number of pods per plant, dry pod weight, dry grain yield and dry fodder yield were significantly higher in Otobi than Makurdi probably because the environmental factors for cowpea production (e.g.rainfall, soil requirement, temperature) might have been more favorable in Otobi than in Makurdi. Generally, more cowpea is produced in Otobi area than in Makurdi (BNARDA, 2003).

The significant effect of variety and non-significant effects of cropping systems with variety interaction on the DF and DM showed that attainment of reproductive phase was a varietal characteristic as a result of genetic constitution of the varieties .Similar findings had been reported by Egbe (2005) while evaluating pigeonpea genotypes for intercropping with maize at Otobi and Muoneke et al (2007) in their study on effect of maize planting density on the performance of maize/soybean intercropping system in a guinea savannah agro ecosystem. The cropping system $x$ cowpea variety interactions were consistently not significant for all the characters measured. Wein and Smithson (1981) had demonstrated significant interaction of genotype $x$ cropping systems in their study on cowpea. Such significant interactions are important for the selection of varieties for intercropping. Intercropping reduced the number of branches per plant and the grain yield of cowpea as compared to sole cropping, but this varied with variety. Katsaruware and Manyanhaire (2009) had reported differential percentage yield reductions (16.5\%-37.2\%) among cowpea varieties intercropped with maize in Zimbabwe. Idoko (2005) also observed that cowpea grain yield declined significantly in Makurdi,Nigeria, under intercropping as compared to sole cropping, and further reported that such decline varied with the genotype of cowpea used. These workers attributed the reductions to interspecific competition as well as shading of the cowpea by the taller maize component. The increased number of branches of Ife Brown under intercropping which did not result in increased pod or grain yield may need further investigation.

Sole maize gave significantly higher ear length, cob length, dry cob weight, dry grain yield and total plant biomass than intercropped maize. This result could be due to a higher degree of competition in mixed stands as compared to sole cropping. Katsaruware and Manyanhaire (2009) had stated that absence of interspecific competition in sole cropping leads to 
Agric. Biol. J. N. Am., 2010, 1(5): 845-858

better access to growth factors to support growth, development and subsequently yield than in intercropping systems. Similarly, Liebman and Dyck (1993) indicated that maize yield was observed to be depressed by $12-22 \%$ when intercropped with a legume, mainly due to competition for water and nutrients.

LER values were greater than unity in IT04K-2211,IT03K-316-1,IT00K-1217, and IT03K-324-9 cowpeas combined with maize at Otobi, indicating the advantage of intercropping over sole stands in regard to use of environmental growth resources. The results of this study showed that between $8 \%$ and $46 \%$ more land would be required under sole systems to obtain the same amount of grain yield compared to intercropping. In the same vein, only IT04K-221-1 and IT03K-316-1 produced ATER values beyond 1.0, showing further advantage of intercropping these cowpea varieties with maize in Southern Guinea Savannah. The ATER figures obtained in this study implied that between $2 \%$ and $22 \%$ more hectare days would be required under sole cropping than when these two varieties of cowpea were intercropped with maize. Again intercropped IT04K-221-1 with maize had the highest LEC value, and a few other intercropped cowpeas with LEC values above 0.25 included IT03K-316-1,IT03K-3249 and ITO3K-351-1.Adetiloye et al.(1983) stated that the minimum expected production before a yield advantage is obtained in a two-crop mixture is an LEC greater than 0.25 ,i.e., a productivity coefficient greater than $25 \%$.

Several cowpea varieties had $K$ cow above 1.0 (IT03K-316-1, IT99K-377-1, IT98K-692, IT04K-221-1, IT03K-324-9 and Ife Brown) indicating an absolute yield advantage of these cowpea varieties when intercropped with maize. Yilmaz et al.(2008) had reported similar findings in maize- legume intercropping systems in the East Mediterranean region. $K$ cow were generally higher than $K$ ma suggesting greater competition from the cowpea component. This result may be possible due to far higher population density of cowpea per unit area(10 plant $\mathrm{m}^{-2}$ ) as compared to 4 plants of maize $\mathrm{m}^{-}$ ${ }^{2}$.Although maize is known to have profuse and dense root system, cowpea is endowed with deep and extensive roots that explore greater soil surface especially with this population advantage. Yilmaz et al.(2008) had made similar observations when maizelegume intercropping was considered in close rates such as 50:50 or 67:50 ratios, competition among the plants seemed to be against maize while it was in favor of cowpea .Other indices of competition (competitive ratio and aggressivity) used in the evaluation of the intercropping advantages showed that cowpea was the more competitive intercrop component, probably because of the higher population advantage and also the inherent ability of the cowpea to fix nitrogen $(N)$ to meet its $N$ requirement when under competition, unlike maize. Ofori and Stern (1987) had reported that up to $41 \mathrm{~kg}$ $\mathrm{N} /$ ha could be fixed by the cowpea component of cowpea/maize intercropping.

Sole cowpea had a mean net benefit of $-\$ 560.00 /$ ha, while intercropped cowpea gave a mean value of $\mathrm{N}$ $11330.00 / \mathrm{ha}$, implying that growing extra-early- and early-maturing cowpea in sole systems would result in losses. This result further revealed the advantage of intercropping systems as being more remunerative than sole cropping. However, growing some of these varieties (IT98K-692, IT03K-324-9 and IT03K-351-1) in sole systems was more profitable than when intercropped.

IT04K-221-1produced the highest dry pod weight, grain yield, total plant biomass under intercropping and gave the highest LER, ATER, and LEC values. It also resulted in the highest net benefit under intercropping with maize. This superior performance may have resulted from among other things, the nondepressive effect of intercropping on its branching. The number of branches and nodes and increased internode length are plant traits that are important under intercropping (Nelson and Robichaux, 1997).The better performance of this early-maturing cowpea line, along with a few others(e.g.IT03K-3161,IT03K-324-9,IT98K-692 and IT00K-1217) than the check suggested that these varieties could be recommended for adoption after further testing onfarm.

\section{CONCLUSION:}

The present study concludes that intercropping these extra-early- and early-maturing cowpea varieties with maize resulted in depressed branching, dry pod weight and dry grain yield of the cowpea component, but the level of depression varied with the cowpea variety. Intercropping also reduced the ear length, cob length, dry cob weight, dry grain yield and total plant biomass of the maize component. Measures of intercrop advantage (LER, ATER, and LEC) revealed that some of these cowpea varieties ( IT04K-2211, IT03K-316-1, IT03K-324-9, IT98K-692 and IT00K2117 ) could be intercropped with maize with resultant yield advantage. It is also concluded that growing these extra-early- and early-maturing cowpea under intercropping was more profitable than growing them 
in sole systems. IT04K-221-1 cowpea was the most productive variety and gave the highest net benefit.

\section{REFERENCES:}

Adetiloye, P.O., F.O.C. Ezedinma and B.N. Okigbo. 1983. A land equivalent coefficient concept for the evaluation of competitive and productive interactions on simple complex mixtures.Ecol.modelling.19:27-39.

Ajibade, S.R. and J.A.Morakinyo 1999. Hertability and correlation studies in cowpea (Vigna unguiculata (L.) Walp).Nig.J.of Gen. 14:

Attah, E.S. 2002. Evaluation of maize-cowpea intercrop with selected cowpea (Vigna unguiculata (L.) Walp) cultivars, plant density and row arrangement. Ph.D thesis, University of Agriculture,Makurdi,135pp.

Banik, P., A. Midya, B.K..Sarkar and S.S. Ghose. 2006. Wheat and chickpea intercropping systems in an additive series experiment: advantages and weed smothering .Eur.J.Agron.24:325.332

Blade, S.F., D.F. Mather, B.B Singh and B.B Smith 1992.Evaluation of yield stability of cowpea under sole and intercrop management in Nigeria. Eupht.61:193-201

Bnarda (1999). Benue State Agricultural and Rural Development Authority .On-farm research trials report. Technical paper presented at Middlebelt Zonal Workshop on farming systems research and extension,Makurdi, Nigeria,32pp.

Bnarda (2003).Benue State Agricultural and Rural Development Authority: Annual Report,2003,Makurdi, Nigeria.

Bnarda (2009).Benue State Agricultural and Rural Development Authority. PME Status Report and 2010 Planned Work Programme, Makurdi, Nigeria.

Craufurd,P.Q. 1996. Effect of plant population density on dry matter partitions and yield in short duration cowpea (Vigna unguiculata) grown in the Tropics. J. Agric. Sci.Camb.127:89-96

Dugje, I.Y., L.O. Omogui, F. Ekeleme, A.Y. Kamara, and H.Ajeigbe.2009.Farmers, Guide to Cowpea Production in West Africa.IITA, Ibadan,Nigeria.20 pp.

Egbe, O.M.2005.Evaluation of agronomic potentials of some pigeonpea genotypes for intercropping with maize and sorghum in Southern Guinea Savanna. Ph.D thesis, University of Agriculture, Makurdi, Nigeria.

Ezumah, H.C. and J.E.G. Ikorgu.1992.Population and planting pattern effects on intercropped maize and cowpea. J.of Agron.Crop Sci. 170(3):187-194.

Ghosh PK ,Manna MC, Bandyopadhyay KK, Ajay ,Tripathi AK, Wanjari RH, Hati KM, Misra AK,Acharya CL, Subba Rao (2006).Interspecific interaction and nutrient use in soybean/sorghum intercropping system.Agron. J.98:10971108

Hiebisch, C.K. and R.E.McCollum.1987.Area x time equivalency ratio: a method of evaluating productivity of intercrops.Agron. J.79:15-22.

Idoko, J.A. 2005.Effects of cultivars and time of introducing cowpea on the performance of maize/cowpea intercropping systems in Makurdi. Ph.Dthesis,University of Agriculture,Makurdi(unpublished).
Jackson, M.L. 1967.Soil chemical Analysis.Prentice Hall,Englewood Cliff,N.S.498PP.

Katsaruware, R.D. and I.O.Manyanhaire. 2009. Maize-cowpea intercropping and weed suppression in leaf stripped and detasselled maize in Zimbabwe. Elect.J. Environ.Agric. Food Chem. 8 (11).1218-1226.

Kowal, J.M. and D.T.Knabe.1972.An agro-climatological Atlas of Northern States of Nigeria.Ahmadu Bello University Press, Zaria.

Liebman, M. and E. Dyck. 1993.Crop rotation and intercropping strategies for weed management.Ecol. Appl.3(1):92-122

Muoneke, C.O., M.A.O.Ogwuche and B.A.Kalu.2007.Effect of maize planting density on the performance of maize/soybean intercropping system in a guinea savannah agroecosystem.Afr.J.Agric.Res. 2(12):667-677

Nelson, S.C. and R.H.Robichaux.1997.Identifying plant architecture traits associated with yield under intercropping: implications of genotype-cropping system interactions.Plant Breeding 16:163-170.

Ofori $F$ and Stern WR (1987).Cereal -legume intercropping systems.Adv.Agron.41:41-90

Ogbuinya, P. 1997.Advances in cowpea research.Biotech. Dev.Monitor 33:1012.

Olufajo, O.O. and B.B. Singh. 2002. Advances in cowpea cropping systems research. Http//:www.iita.org/details/cowpea.

Putnam D.H, Herbert SJ and Vargas A (1984). Intercropped corn soybean density studies. 1. Yield complementarity. Expl. Agric. 21: 41-51.

Singh, B.B. and B.R.Ntare.1985.Development of improved cowpea varieties in Africa.In:S.R.Singh and K.O.Rachie (eds).Cowpea Research,Production and Utilization.John Willey and Sons.pp 105-115.

Singh, B.B., O.L.Chambliss and B.Sharma. 1997. Recent advances in cowpea breeding.In: B.B.Singh,D.R.Mohan Raj,K.E.Dashiell and L.E.N.Jackai (eds).Copublication of International Institute of Tropical Agriculture (IITA) and Japan International Research Centre for Agricultural Sciences (JIRCAS0.IITA, Ibadan,Nigeria.

Singh, B.B. and H. Ajeigbe .2007. Improved cowpea-cerealsbased cropping systems for household food security and poverty reduction in West Afica.J.Crop Improvement.19 91\&2):157-172

Singh, B.B., O.O.Olufajo.M.F.Ishyaku, R.A.Adeleke, H.A.Ajeigbe and S.G.Mohammed.2007.J.Plant Reg.1:4849

Snapp,S.S. and S.N. Silim .2002. Farmer preferences and legume intensification for low nutrient environments. Plant and Soil.245:181-192

Wein,H.C .and J.B. Smithson. 1981. Evaluation of genotypes for intercropping .In:proceedings of International workshop on 1 ntercropping,ICRSAT,Hyderabad,India.

Yilmaz, S., M.Atak and M.Erayman. 2008. Identification of advantages of maize-legume intercropping over solitary cropping through competition indices in the East Mediterranean region. Turk. J. Agric.For.32:111-119. 